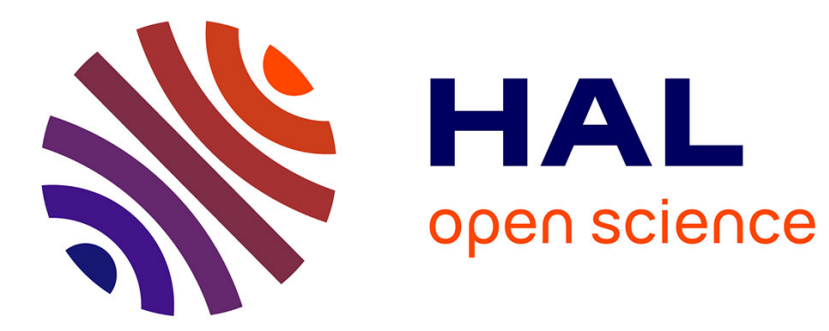

\title{
Understanding SOS (Son of Sevenless)
}

\author{
Stéphane Pierre, Anne-Sophie Bats, Xavier Coumoul
}

\section{To cite this version:}

Stéphane Pierre, Anne-Sophie Bats, Xavier Coumoul. Understanding SOS (Son of Sevenless). Biochemical Pharmacology, 2011, 82 (9), pp.1049-1056. 10.1016/j.bcp.2011.07.072 . hal-02190799

\section{HAL Id: hal-02190799 \\ https://hal.science/hal-02190799}

Submitted on 22 Jul 2019

HAL is a multi-disciplinary open access archive for the deposit and dissemination of scientific research documents, whether they are published or not. The documents may come from teaching and research institutions in France or abroad, or from public or private research centers.
L'archive ouverte pluridisciplinaire HAL, est destinée au dépôt et à la diffusion de documents scientifiques de niveau recherche, publiés ou non, émanant des établissements d'enseignement et de recherche français ou étrangers, des laboratoires publics ou privés. 


\section{Understanding SOS (Son of Sevenless).}

Stéphane PIERRE ${ }^{1,2, \$}$, Anne-Sophie BATS ${ }^{1,2,3, \sharp}$, Xavier COUMOUL ${ }^{1,2, \dagger}$

${ }^{1}$ INSERM UMR-S 747, Toxicologie Pharmacologie et Signalisation Cellulaire, 45 rue des Saints Pères, 75006 Paris France

${ }^{2}$ Université Paris Descartes, Centre universitaire des Saints-Pères, 45 rue des Saints Pères, 75006 Paris France

${ }^{3}$ AP-HP, Hôpital Européen Georges Pompidou, Service de Chirurgie Gynécologique Cancérologique, 75015 Paris France

${ }^{\ddagger}$ These authors contributed equally to this work.

†Address correspondence to: Xavier Coumoul, INSERM UMR-S 747, 45 rue des Saints-Pères 75006 Paris France; Phone: +33 1428633 59; Fax: +33 1428638 68; E-mail: xavier.coumoul@parisdescartes.fr

Key words: Son of Sevenless. Ras. Guanine Nucleotide Exchange Factors. Rac Guanine Nucleotide Exchange Factors. Noonan Syndrome. Dioxin. Carcinogenesis. 


\section{Abbreviations}

AhR: Aryl hydrocarbon Receptor

Cdc 25: Cell division cycle 25

CFC: Cardio-Facio-Cutaneous Syndrome

DH: Dbl homology

E3b1: Eps8 SH3 domain binding protein 1

Eps8: EGFR pathway substrate 8

ERK: Extracellular signal-Regulated protein Kinase

Grb2: Growth factor receptor bound 2

FAK: Focal Adhesion Kinase

MAPK: Mitogen Activated Protein Kinase

MEK: MAP ERK Kinase

NS: Noonan Syndrome

PH: Pleckstrin Homology

PTB: Phosphotyrosine Binding

PTPN: Tyrosine-protein phosphatase non-receptor type 1

PxxP: Proline rich domain

REM: Ras Exchange Motif

SOS: Son of Sevenless

TCDD: 2,3,7,8-TetraChloroDibenzoDioxin

TGF: Tumor Growth Factor 


\section{Abstract}

Son of Sevenless (SOS) was discovered in Drosophila melanogaster. Essential for normal eye development in Drosophila, SOS has two human homologues, SOS1 and SOS2 (Figure 1C). The SOS1 gene encodes the Son of Sevenless 1 protein, a Ras and Rac guanine nucleotide exchange factor. This protein is composed of several important domains. The CDC25 and REM domains provide the catalytic activity of SOS1 towards Ras and the histone fold DH/PH (Dbl homology and Pleckstrin homology) domains function, in tandem, to stimulate GTP/GDP exchange for Rac. In contrast to Ras, there have been few studies that implicate SOS1 in human disease and, initially, less attention was given to this gene. However, mutations in SOS1 have been reported recently in Noonan syndrome and in type 1 hereditary gingival fibromatosis. Although, there have been very few studies that focus on the regulation of this important gene by physiological or exogenous factors, we recently found that the SOSI gene was induced by the environmental toxin, dioxin, and that this effect was mediated by the aryl hydrocarbon receptor (AhR). These recent observations raise the possibility that alterations in the expression of the SOS1 gene and, consequently, in the activity of the SOS1 protein may affect toxicological endpoints and lead to clinical disease. These possibilities, thus, have stimulated much interest in SOS1 recently. In this article, we review the functions of SOS1 and the evidence for its roles in physiology and pathology across species. 


\section{Discovery of Son of Sevenless (SOS)}

The work of Bonfini et al on drosophila eye development led to the discovery of the SOS (Son of Sevenless) protein [1]. During eye development, a cluster of eight photoreceptor neurons autonomously develops in each ommatidium [2, 3]. An ommatidium contains 8 photoreceptor cells (R) surrounded by support cells and pigment cells. The ommatidium is the functional unit of the drosophila eye and it is composed of a majority of R cells (photosensing cells) with one central R8 cell. These cells are the first to express neuronal markers [4-6]. Within the ommatidium, R8 directly induces a neighboring cell to develop into the R7 photoreceptor neuron. This induction is mediated by Bride of Sevenless protein (Boss), a transmembrane protein localized on the surface of R8 cells. Boss binds and activates sevenless (Sev), a tyrosine kinase receptor expressed by R7 on its cell membrane [7]. These two proteins are essential for R7 cell development and ultimately lead to Ras1 activation [8]. In fact, a genetic screening study in Drosophila has shown that seven genes are essential for Sevenless signaling among which are a Ras protein and a protein homologous to S. cerevisae $C D C 25$ [9], which is known to promote exchange of guanine nucleotide phosphate bound to Ras [10]. The interaction between Sev and Ras1 is not direct and requires additional factors including Son of Sevenless (SOS). SOS has been found to be a critical member of the signal transduction pathway initiated by the Sevenless receptor [11].

SOS homologues were subsequently discovered and characterized in other species. Essential roles for let 23 (which encodes a putative tyrosine kinase of the epidermal growth factor (EGF) receptor subfamily) and SOS homologues have been documented during vulval development, oocyte maturation and uterine differentiation in Caenorhabditis elegans [12, 13]. Several laboratories discovered and characterized two murine homologues of Drosophila Son of sevenless, mSOS1 and mSOS2 [14-16]. The lack of mSOS1 protein in mice leads to mid-gestation embryonic death related to placental alterations and potentially associated heart failure [17]. On the other hand, lack of $\operatorname{mSOS} 2$ has not be found to be associated with abnormalities of mouse growth and development [18].

Thus, the SOS1 gene is essential for normal development in fruit fly, nematode, mouse and man. 


\section{Structure and Function of Son of Sevenless 1}

Two human SOS homologues, hSOS1 and hSOS2 (Figure 1C), have been identified [19]. These genes map to 2 p22-->p16 and 14q21-->q22, respectively, in the human genome. SOS1 is well conserved in drosophila, mice and humans. There is a $30 \%$ amino acid homology between hSOS1 and Drosophila SOS, $65 \%$ between hSOS1 and mouse SOS1 and a $70 \%$ homology between human SOS1 and SOS2 (figure 1A).

The hSOS 1 protein $(150 \mathrm{kDa})$ is composed of 1300 amino acids with several domains and it functions as a Ras and Rac guanine nucleotide exchange factor [20]. Ras proteins are small monomeric proteins from the G protein family, which bind GTP. The conversion of the inactive GDP bound form of Ras to the active GTP bound form is promoted by guanine nucleotide exchange factors like CDC25 and SOS1.

The C-terminal segment of hSOS1 has a proline-rich domain (PXXP). This domain interacts with the SH3 domains (Src Homology 3) of proteins such as Grb2 (Growth factor receptor bound 2, Figure 1B) for Ras and E3B1 for Ras [21].

In its central segment, SOS1 has two domains, REM (Ras Exchanger Motif) and CDC25 (cell division cycle 25). CDC25 activates Ras in yeast and promotes nucleotide exchange on Ras proteins. This catalytic site has a hairpin structure, stabilized by REM alpha helices, forming a hydrophobic pocket. The REM domain contains an activating allosteric site which binds Ras-GTP leading to additional stimulation of the CDC25 domain and potentiating the Ras-GTP exchange stimulated by SOS1.

The N-terminal segment contains two tandem histone folds, the Dbl homology (DH) and the Pleckstrin Homology domain (PH). The two histone folds have two roles. First, they inhibit exchange activity for Rac1 by binding to the PH domain [21] and second, they are responsible for interaction with the cell membrane [22]. The catalytic DH domain allows the activation of Rac, which, classically, is described as a regulator of cell morphology and the cytoskeleton via its connections with actin filaments. The $\mathrm{PH}$ domain regulates the $\mathrm{DH}$ domain, but the associated mechanisms are still unknown. In addition, both the DH and PH domains inhibit the activation of Ras. 


\section{Regulation of the Ras and Rac Pathways by Son of sevenless 1}

Although the role of SOS1 as a nucleotide exchanging factor important for the activation of Ras and/or Rac has been explored extensively, the balance of the activation between Ras and Rac is still not well understood.

\section{Ras pathway}

Active Ras plays a fundamental role in growth and cellular differentiation and the Ras pathway is involved in the aberrant regulation of malignant transformation. The active form of Ras activates the RAF1/Mitogen-Activated Protein Kinase (MAPK)/extracellular signalregulated protein kinase (ERK) signaling pathway (figure $2 \mathrm{~A}$ ), which is crucial for cell proliferation, transformation, survival and mobility. Overactivation of this pathway is very often described in carcinogenesis [23-26].

Activation of the Ras and MAPK pathways can be initiated by tyrosine kinase receptors (insulin receptor, EGFR, PDGFR) [27]. In addition to tyrosine kinase receptors, B cell, T cell and Monocyte colony-stimulating factor receptors are able to activate Ras through the SOS pathway [28]. When a ligand (for example, EGF or Epidermal Growth Factor) binds to its transmembrane tyrosine kinase receptor (EGFR), it activates the auto-phosphorylation of the receptor. The adaptator protein, Grb2 (Growth factor receptor-bound protein 2) via its SH2 (Src Homology 2) domain, binds this phosphotyrosine (figure 2B) [29, 30]. Grb2 is a small ubiquitously expressed protein $(25 \mathrm{kDa})$, which has a central SH2 domain flanked by 2 SH3 domains. It can interact directly with RTK (EGFR or Hepatocyte Growth Factor Receptor) or indirectly by the intermediate of docking proteins (FRS2 for Fibroblast Growth Factor Receptor signaling or IRS for Insulin Receptor signaling). It can also interact with nonRTK proteins such as Focal Adhesion Kinase [31]. Moreover, Grb2 is highly conserved throughout evolution and it is essential for development. Grb2 knock out mice die at early embryonic stage [29]. The binding of Grb2 to a RTK triggers the recruitment of cytosolic SOS1 to the cell membrane. The SH3 domain of Grb2 binds to the proline-rich C-terminal domain of SOS1, a phenomenon which is a prerequisite for the activation of Ras [32] (figure 2C). Two domains are essential for SOS1 membrane relocalization: the proline-rich Cterminal domain and the N-terminal PH domain, which interacts with the phosphatidic acid that has been generated by phospholipase D2-activation by growth factors [33]. SOS1 relocalization to the cell membrane, enables its interaction with Ras. As previously noted, the 
interaction with Ras involves two domains of SOS1: the CDC25 domain which has the active

site for the nucleotide exchange and the REM domain which contains a recently identified allosteric site responsible for the release of the autoinhibition of the DH-PH domains and which activates the tandem histone folds [34]. Allosteric activation of SOS1 by Ras occurs through a rotation of the REM domain that is coupled to a rotation of a helical hairpin at the SOS1 catalytic site. This motion relieves the steric hindrance of the catalytic site, allowing Ras binding and nucleotide exchange (figure 2C) [35].

The activity of this signaling pathway is ultimately controlled by feedback mechanisms targeting SOS1. A serine/threonine phosphorylation of SOS1 in its C-terminal domain by Mitogen Activated Protein Kinase (MAP Kinase) has been described which may alter its association with Grb2 and inhibit SOS1 function [36-38]. Further, the binding of an antagonist (p27 KIP1, SPROUTY 1 to 4) to Grb2 prevents its binding to SOS1 [39]. Oxidative stress also has been shown to inhibit the EGFR signaling pathway by activating the binding of p66(SHC) to EGFR and Grb2 and promoting the dissociation of Grb2 from SOS1 [40].

\section{Rac pathway}

Rac proteins belong to the RHO family. Active Rac forms are also bound to GTP. These proteins play a role in the reorganization of the actin cytoskeleton (figure 2B). Moreover, Rac activates c-Jun N-terminal kinase (JNK) [41, 42] via the recruitment of a scaffold protein POSH (plenty of SH3) which, in turn, activates MKK 4 and 7 and the MAPK pathway [43]. JNK is also involved in cell proliferation, survival, differentiation and apoptosis. Thus, some of the functions of Rac might be redundant with those of Ras.

SOS1 is a Rac nucleotide exchange factor which stimulates the reorganization of the actin cytoskeleton (ruffling membranes, lamellipodia protrusions), cell invasion and migration. The partners of SOS1 in this pathway are different from those involved in the Ras pathway. Upon Rac activation, SOS1 associates with the cytoplasmic EPS8-E3B1 proteins (Figure 2D). The EGFR pathway substrate 8 (EPS8), a substrate of the EGFR kinase, contains three major domains: an N-terminal phosphotyrosine binding (PTB) domain, a central SH3 domain and a C-terminal "effector region" domain. The effector domain enables EPS8 cellular localization, possibly through its interaction with distinct sets of actin regulatory complexes, and allows Rac activation. The EPS8-SH3 domain binds a PxxP domain of E3B1, the SH3 domain of which binds the PxxP domain of SOS1 [44]. The EPS8-E3B1-SOS1 
complex, linked to actin filaments through EPS8, activates Rac (upon binding with the

CDC25 domain) and subsequently, c-JUN N-terminal kinase and MAPK (see above) enabling actin cytoskeleton remodeling. Other membrane receptors that are known to regulate cytoskeleton organization and migration have been shown to regulate Rac through SOS1. For example, integrins activate the phosphoinositide 3-kinase (PI 3-kinase) pathway which disrupts the PH-DH interaction in SOS1 and opens the Rac binding domain [45].

Although the Ras pathway has been clearly characterized, the regulation of the Rac pathway by SOS1 is poorly characterized in spite of the fact that it is critical for the regulation of lamellipodia protrusion, cell migration and invasion. E3B1 is a limiting factor since it binds SOS1 as well as Grb2. The regulation of the EPS8-E3B1-SOS1 and SOS1-Grb2 complexes could involve tyrosine kinase receptors. The p66SHC protein (see above) specifically activates Rac, decreasing the formation of the SOS1-Grb2 complex (and the activation of Ras) and increasing the formation of the SOS1-EPS8-E3B1 complex [46].

\section{Human Disorders Associated With Dysfunctions of Son of sevenless 1}

Recent clinical studies have indicated a potential implication of SOS1 in both the Noonan syndrome and hereditary gingival fibromatosis type 1 .

\section{Noonan syndrome (NS) and cardio-facio-cutaneous syndrome (CFC)}

The NS and CFC syndromes are autosomal dominant disorders characterized by cardiac defects, facial dysmorphism, ectodermal abnormalities and mental retardation. The genetic mutations discovered in these syndromes are associated with abnormal Ras/RAF/MEK/ERK signaling [47].

NS patients exhibit facial dysmorphism (broad forehead, downslanting palpebral fissures, hypertelorism, low-set posteriorly rotated ears and a high arched palate), curly hair, short stature, skeletal anomalies and heart defects. They may also have pulmonary artery stenosis, hypertrophic cardiomyopathy, chest abnormalities, mental retardation and genitourinary anomalies. The incidence of the disease is $1 / 1000$ to $2500[48,49]$. Sixty per cent of NS cases are sporadic [48]. Mutations of the PTPN11, KRAS, RAF1 genes and, recently, the SOS1 gene were found in patients with NS. Mutations of PTPN11 are the most frequently reported (50\%) and they lead to activation of the Ras/MAPK pathway. These mutations are "gain of function" mutations, which are associated with increased risk of leukemia, 
myeloproliferative disorders and solid tumors [50, 51]. SOS1 mutations are found in 15 to $20 \%$ of NS and are affect in Ras/ERK activation. Patients with SOS1 mutations exhibit a phenotype composed of curly hair and ectodermal abnormalities. Constant activation of the Ras/ERK pathway is due to mutations in SOS1 principally in two domains, the Pleckstrin Homology (PH) and the Ras Exchanger Motif (REM) domains, which are not implicated in the exchange activity but rather in the intrinsic inhibitory function of SOS1. These mutations lead to the maintenance of SOS1 in a non-inhibited form. This is the first example of an activating GEF mutation associated with human disease [47, 48, 52].

CFC syndrome resembles NS and is characterized by mental retardation, facial abnormalities, cardiac defects and ectodermal abnormalities (sparse hair, dry and hyperkeratotic skin). Mutations responsible for this syndrome involve the $K R A S, B R A F$, MEK1 and MEK2 genes. Only a few SOS1 mutations have been reported [53].

\section{Hereditary gingival fibromatosis type 1}

Hereditary gingival fibromatosis type 1 is a rare, autosomal dominant, gingival hypertrophy. It is a benign disease resulting in a progressive, non-hemorrhagic enlargement of the gingival mucosa [54]. This pathology is associated with a SOS1 mutation in the prolinerich C-terminal domain, which normally allows the recruitment of SOS1 by Grb2 [54]. Interestingly, the mutation induces constitutive SOS1 membrane recruitment, spontaneous activation of the Ras/MAPK pathway and, thus, cell proliferation. In gingival fibroblasts, there is an increase of the intensity and the duration of the MAPK signal, which favors the transition from G1 to S phase. The reasons as to why the hypertrophy is confined only to the gingival tissue, remain undetermined [55].

In addition to its participation in gingival fibromatosis, increased expression of SOS1 has been shown to be necessary for gingival healing. SOS1 overexpression is caused by a cascade of intracellular signals induced by growth factors and cell adhesion receptor like integrins [56].

\section{SOS1 and carcinogenesis}

Besides NS and hereditary gingival fibromatosis type 1, a few other clinical manifestations have been related to SOS1. Historically, mutations of SOS1 have not been reported to be pro-oncogenic in NS [51] but recently this has been challenged. In fact, overexpression of SOS1 is known to activate the Ras pathway and, thus, to promote both proliferation and differentiation [23]. SOS1-Grb2 binding and activation of the Ras/MAPK 
pathway are promoted by ionizing radiation, which ultimately stimulates growth of human breast cancer [57]. The link with carcinogenesis would seem, thus, to be a propitious area of investigation. Denayer et al have shown that NS patients with SOS1 mutations sometimes display tumors including embryonal rhabdomyosarcomas, Sertoli cell testis tumors, or granular cell tumors of the skin [58]. Further, the amplification of Grb2 and SOS1 seems to play a role in the etiology of bladder cancer [59]. A recent study has demonstrated that in African-American men, SOS1 expression is enhanced in prostate cancer epithelial cells [60]. Similarly, overexpression of SOS1 has been demonstrated in immortalized human kidney cancer cell lines [61]. Involvement of EGFR and SOS1 has been incriminated, also, in nonsmall cell lung carcinomas and in some skin cancers. Indeed, Sibilia et al showed that a transgenic mouse model expressing a dominant form of Son of Sevenless (SOS-F) in basal keratinocytes developed skin papillomas with $100 \%$ penetrance and demonstrated a cellautonomous requirement for EGFR [62]. The role of SOS1 has been highlighted, also, in certain hematological malignancies. For example, in chronic myeloid leukemia, Grb2 interacts with the fusion protein, BCR-ABL, and prevents its binding to SOS1 [63]. Finally, Moeller et al have shown that p27Kip1, a protein that inhibits the association between Grb2 and SOS1, often is reduced in aggressive cancers [64]. All these observations provide additional arguments in favor of the involvement of SOS1 in cancer.

\section{Activation of the Expression of Son of Sevenless 1}

SOS1 is known to play a role in different cellular processes. Its germ-line mutations induce a variety of developmental diseases and SOS1 dysfunction and the overexpression of mutant forms of SOS1 are involved in cancer development. Nevertheless, no transcriptional activator of SOS1 had been discovered until recently. Gene expression data from our laboratory and from that of another group [65], derived from rat hepatocytes, have unraveled the potential regulation of SOS1 by an environmental pollutant, 2,3,7,8Tetrachlorodibenzodioxin (TCDD). TCDD, which is the most studied dioxin, is a highly persistent contaminant of the environment. It was listed in 1997 as a "human carcinogen" by the International Agency for Research on Cancer (IARC). TCDD is the ligand with the highest affinity of Aryl hydrocarbon Receptor (AhR). The toxic effects of TCDD, including tumor promotion and carcinogenesis, are mediated by the AhR. The AhR is a transcription 
factor which induces the expression of target genes, such as those encoding xenobiotic metabolizing proteins.

Our microarray gene expression analysis constituted the first attempt to study the regulation of the previously uncharacterized SOS1 promoter by the AhR and its ligands in the human hepatoblastoma cell line, HepG2 [66]. We found that the levels of SOS1 mRNA and protein are up-regulated following treatment with TCDD (RT-PCR, Western blot) and that this process occurs at the transcriptional level. Chromatin immunoprecipitation showed that the AhR binds to the SOS1 promoter and luciferase gene reporter assays showed activation of the SOS1 promoter following this binding. Thus, TCDD-mediated transcriptional regulation of SOS1 is related to the rapid, direct binding of the AhR to the SOS1 promoter.

We also analyzed the consequences of the SOS1 transcriptional regulation by the AhR on the Ras and Rac pathways. Although we were not able to observe Rac stimulation upon TCDD treatment, we did find that TCDD stimulates Ras activity (enhancement of Ras-GTP) and subsequent ERK1/2 phosphorylation. SOS1 is critical not only for this stimulation (as shown by RNA interference experiments blocking SOS1 induction) but also for dioxindependent changes in cell growth. This is the first time that SOS1 overexpression has been associated with increased activity of the Ras pathway. The AhR is able to bind thousands of environmental pollutants including dioxins, furans and polycyclic aromatic hydrocarbons (tobacco smoke, barbecued food, air pollution) and the induction of SOS1 by this signaling pathway might be critical for the growth of cancer cells (Figure 3). Although this phenomenon does not require a mutant form of SOS1, it is clearly in accord with recent studies that suggest a role for SOS1 in carcinogenesis $[58,60,62,67,68]$.

\section{Conclusion}

SOS1 was identified in the early 1990's as a member of the Ras signaling pathway. It was quickly identified as a Ras and Rac guanine nucleotide exchange factor. Following the complete characterization of the Ras pathway, subsequent studies have focused on the role of Ras as a significant contributor to numerous tumorigenic processes. Also, recent studies have demonstrated SOS1 dysfunction in several diseases including cancer or cardio-faciocutaneous syndrome. Gain of function mutations of SOS1 stabilize the protein thus stimulating the Ras pathway. One recent study also has suggested that overexpression of the normal protein stimulates the Ras pathway and cell growth [66]. This may result from 
exposure to an environmental pollutant and stimulation of a pleiotropic xenobiotic receptor, called AhR. Thus, AhR ligands, which are present extensively in the environment, might stimulate cell growth through stimulation of SOS1 expression. Interestingly, this is not the only study indicating a potential link between SOS1 and the AhR. In Drosophila Melanogaster, Spineless, the AhR orthologue, regulates the development of the ommatidium and the proper institution of color vision by the retinal mosaic [61]. Color vision requires both R7 and R8 photoreceptor cells. As previously noted, this is an interesting parallel with the fundamental role of Son of Sevenless in the development of the R7 photoreceptor neuron. Other observations suggest that SOS1 regulation by the AhR could be relevant in vivo. Dioxin has been shown to induce developmental abnormalities including cleft palate. This is due to the disruption of the spatial and temporal expression of EGF and TGF $\beta$ and the dysfunction of their associated downstream pathways [69-71]. Based upon the recent cancer literature describing gain-of-function effects of SOS1, it appears to us that fruitful areas for future work involve the characterization of SOS1 transcriptional regulation and potential stimuli that could enhance the Ras signaling pathway and physiopathological processes.

\section{Acknowledgements}

This work was supported by AFSSET (Agence Française de Sécurité Sanitaire de l'Environnement et du Travail; all authors); the ANR (Agence Nationale de la Recherche, 06SEST26, Oncopop; all authors); ARC (Association pour la Recherche sur le Cancer, 3927; all authors); the CNRS (Centre Nationale de la recherche scientifique); the Fondation pour la Recherche Médicale; the Hopitals «Européen Georges Pompidou» and «Necker»; the INSERM (Institut National de la Santé et de la Recherche Médicale; all authors); the Ligue contre le Cancer (Bourse post-doctorale); the Ministère de l'enseignement supérieur et de la recherche; the Région Ile de France (bourse doctorale, Stéphane Pierre); the Université Paris Descartes. We warmly thank Dr Lawrence Aggerbeck for his critical reading of this manuscript. 


\section{Figure legends}

Figure 1: Organization of SOS 1 and Grb2 domains. (A) Representation of SOS1 orthologs of different species, from fruit fly (SOS), nematode (sos-1), mouse (mSOS1) and human (hSOS1). SOS1 is composed of 7 different domains, each of which possesses, a particular function. (B) Grb2 is a linker protein whose SH2 domain (Src homology 2) binds phospho-tyrosine in tyrosine kinase receptors and whose SH3 domain binds proline-rich domains (for example, in SOS1). (C) Representation of mSOS2 and hSOS2. The numbers above the SOS proteins correspond to amino acids in the primary structure.

Figure 2: SOS1 activates the exchange of GDP and GTP for Ras and Rac and stimulates their associated signaling pathways. (A) The Ras signaling pathway. (B) The Rac signaling pathway. (C, D) Mechanistic representation of Ras activation (C) or Rac activation (D) signaling pathways by SOS1 (see text).

Figure 3: The Aryl hydrocarbon Receptor (AhR) transcriptionally triggers SOS1 and subsequently activates the Ras signaling pathway in HepG2 cells. 
References

[1] Bonfini L, Karlovich CA, Dasgupta C, Banerjee U. The Son of sevenless gene product: a putative activator of Ras. Science 1992;255:603-6.

[2] Banerjee U, Zipursky SL. The role of cell-cell interaction in the development of the Drosophila visual system. Neuron 1990;4:177-87.

[3] Ready DF, Hanson TE, Benzer S. Development of the Drosophila retina, a neurocrystalline lattice. Dev Biol 1976;53:217-40.

[4] Tomlinson A, Bowtell DD, Hafen E, Rubin GM. Localization of the sevenless protein, a putative receptor for positional information, in the eye imaginal disc of Drosophila. Cell 1987;51:143-50.

[5] Tomlinson A, Ready DF. Cell fate in the Drosophila ommatidium. Dev Biol 1987;123:264-75.

[6] Tomlinson A, Ready DF. Neuronal differentiation in Drosophila ommatidium. Dev Biol 1987;120:366-76.

[7] Kramer H, Cagan RL, Zipursky SL. Interaction of bride of sevenless membranebound ligand and the sevenless tyrosine-kinase receptor. Nature 1991;352:207-12.

[8] Fortini ME, Simon MA, Rubin GM. Signalling by the sevenless protein tyrosine kinase is mimicked by Ras1 activation. Nature 1992;355:559-61.

[9] Simon MA, Bowtell DD, Dodson GS, Laverty TR, Rubin GM. Ras1 and a putative guanine nucleotide exchange factor perform crucial steps in signaling by the sevenless protein tyrosine kinase. Cell 1991;67:701-16.

[10] Jones S, Vignais ML, Broach JR. The CDC25 protein of Saccharomyces cerevisiae promotes exchange of guanine nucleotides bound to ras. Mol Cell Biol 1991;11:2641-6.

[11] Rogge RD, Karlovich CA, Banerjee U. Genetic dissection of a neurodevelopmental pathway: Son of sevenless functions downstream of the sevenless and EGF receptor tyrosine kinases. Cell 1991;64:39-48.

[12] Aroian RV, Sternberg PW. Multiple functions of let-23, a Caenorhabditis elegans receptor tyrosine kinase gene required for vulval induction. Genetics 1991;128:251-67.

[13] Horvitz HR, Sternberg PW. Multiple intercellular signalling systems control the development of the Caenorhabditis elegans vulva. Nature 1991;351:535-41. 
[14] Bowtell D, Fu P, Simon M, Senior P. Identification of murine homologues of the Drosophila son of sevenless gene: potential activators of ras. Proc Natl Acad Sci U S A 1992;89:6511-5.

[15] Fath I, Apiou F, Schweighoffer F, Chevallier-Multon MC, Ciora T, Dutrillaux B, et al. Identification of two human homologues to Drosophila SOS (son of sevenless) localized on two different chromosomes. Nucleic Acids Res 1993;21:4398.

[16] Webb GC, Jenkins NA, Largaespada DA, Copeland NG, Fernandez CS, Bowtell DD. Mammalian homologues of the Drosophila Son of sevenless gene map to murine chromosomes 17 and 12 and to human chromosomes 2 and 14, respectively. Genomics 1993;18:14-9.

[17] Qian X, Esteban L, Vass WC, Upadhyaya C, Papageorge AG, Yienger K, et al. The Sos1 and Sos2 Ras-specific exchange factors: differences in placental expression and signaling properties. EMBO J 2000;19:642-54.

[18] Esteban LM, Fernandez-Medarde A, Lopez E, Yienger K, Guerrero C, Ward $\mathrm{JM}$, et al. Ras-guanine nucleotide exchange factor $\operatorname{sos} 2$ is dispensable for mouse growth and development. Mol Cell Biol 2000;20:6410-3.

[19] Chardin P, Mattei MG. Chromosomal localization of two genes encoding human ras exchange factors: SOS1 maps to the 2 p22-->p16 region and SOS2 to the 14q21-->q22 region of the human genome. Cytogenet Cell Genet 1994;66:68-9.

[20] Nimnual A, Bar-Sagi D. The two hats of SOS. Sci STKE 2002;2002:pe36.

[21] Jorge R, Zarich N, Oliva JL, Azanedo M, Martinez N, de la Cruz X, et al. HSos1 contains a new amino-terminal regulatory motif with specific binding affinity for its pleckstrin homology domain. J Biol Chem 2002;277:44171-9.

[22] Sondermann H, Nagar B, Bar-Sagi D, Kuriyan J. Computational docking and solution x-ray scattering predict a membrane-interacting role for the histone domain of the Ras activator son of sevenless. Proc Natl Acad Sci U S A 2005;102:16632-7.

[23] Buday L, Downward J. Many faces of Ras activation. Biochim Biophys Acta 2008;1786:178-87.

[24] Kolch W. Meaningful relationships: the regulation of the Ras/Raf/MEK/ERK pathway by protein interactions. Biochem J 2000;351 Pt 2:289-305.

[25] Peyssonnaux C, Eychene A. The Raf/MEK/ERK pathway: new concepts of activation. Biol Cell 2001;93:53-62. 
[26] Wellbrock C, Karasarides M, Marais R. The RAF proteins take centre stage. Nat Rev Mol Cell Biol 2004;5:875-85.

[27] Holt KH, Waters SB, Okada S, Yamauchi K, Decker SJ, Saltiel AR, et al. Epidermal growth factor receptor targeting prevents uncoupling of the Grb2SOS complex. J Biol Chem 1996;271:8300-6.

[28] Salojin KV, Zhang J, Meagher C, Delovitch TL. ZAP-70 is essential for the T cell antigen receptor-induced plasma membrane targeting of SOS and Vav in T cells. J Biol Chem 2000;275:5966-75.

[29] Buday L. Membrane-targeting of signalling molecules by SH2/SH3 domaincontaining adaptor proteins. Biochim Biophys Acta 1999;1422:187-204.

[30] Songyang Z, Shoelson SE, Chaudhuri M, Gish G, Pawson T, Haser WG, et al. SH2 domains recognize specific phosphopeptide sequences. Cell 1993;72:767-78.

[31] Gotoh N. Regulation of growth factor signaling by FRS2 family docking/scaffold adaptor proteins. Cancer Sci 2008;99:1319-25.

[32] Wittinghofer F. Ras signalling. Caught in the act of the switch-on. Nature 1998;394:317, 9-20.

[33] Zhao C, Du G, Skowronek K, Frohman MA, Bar-Sagi D. Phospholipase D2generated phosphatidic acid couples EGFR stimulation to Ras activation by Sos. Nat Cell Biol 2007;9:706-12.

[34] Gureasko J, Galush WJ, Boykevisch S, Sondermann H, Bar-Sagi D, Groves JT, et al. Membrane-dependent signal integration by the Ras activator Son of sevenless. Nat Struct Mol Biol 2008;15:452-61.

[35] Freedman TS, Sondermann H, Friedland GD, Kortemme T, Bar-Sagi D, Marqusee S, et al. A Ras-induced conformational switch in the Ras activator Son of sevenless. Proc Natl Acad Sci U S A 2006;103:16692-7.

[36] Buday L, Warne PH, Downward J. Downregulation of the Ras activation pathway by MAP kinase phosphorylation of Sos. Oncogene 1995;11:1327-31.

[37] Douville E, Downward J. EGF induced SOS phosphorylation in PC12 cells involves P90 RSK-2. Oncogene 1997;15:373-83.

[38] Orton RJ, Sturm OE, Gormand A, Wolch W, Gilbert DR. Computational modelling reveals feedback redundancy within the epidermal growth factor receptor/extracellular-signal regulated kinase signalling pathway. IET Syst Biol 2008;2:173-83. 
[39] Bernards A, Settleman J. GEFs in growth factor signaling. Growth Factors 2007;25:355-61.

[40] Arany I, Faisal A, Nagamine Y, Safirstein RL. p66shc inhibits pro-survival epidermal growth factor receptor/ERK signaling during severe oxidative stress in mouse renal proximal tubule cells. J Biol Chem 2008;283:6110-7.

[41] Bazenet CE, Mota MA, Rubin LL. The small GTP-binding protein Cdc42 is required for nerve growth factor withdrawal-induced neuronal death. Proc Natl Acad Sci U S A 1998;95:3984-9.

[42] Weston C, Gordon C, Teressa G, Hod E, Ren XD, Prives J. Cooperative regulation by Rac and Rho of agrin-induced acetylcholine receptor clustering in muscle cells. J Biol Chem 2003;278:6450-5.

[43] Xu Z, Kukekov NV, Greene LA. POSH acts as a scaffold for a multiprotein complex that mediates JNK activation in apoptosis. EMBO J 2003;22:252-61.

[44] Di Fiore PP, Scita G. Eps8 in the midst of GTPases. Int J Biochem Cell Biol 2002;34:1178-83.

[45] Itoh RE, Kiyokawa E, Aoki K, Nishioka T, Akiyama T, Matsuda M. Phosphorylation and activation of the Rac1 and Cdc42 GEF Asef in A431 cells stimulated by EGF. J Cell Sci 2008;121:2635-42.

[46] Khanday FA, Santhanam L, Kasuno K, Yamamori T, Naqvi A, Dericco J, et al. Sos-mediated activation of rac1 by p66shc. J Cell Biol 2006;172:817-22.

[47] Nystrom AM, Ekvall S, Berglund E, Bjorkqvist M, Braathen G, Duchen K, et al. Noonan and cardio-facio-cutaneous syndromes: two clinically and genetically overlapping disorders. J Med Genet 2008;45:500-6.

[48] Noordam K. Expanding the genetic spectrum of Noonan syndrome. Horm Res 2007;68 Suppl 5:24-7.

[49] van der Burgt I. Noonan syndrome. Orphanet J Rare Dis 2007;2:4.

[50] Roberts AE, Araki T, Swanson KD, Montgomery KT, Schiripo TA, Joshi VA, et al. Germline gain-of-function mutations in SOS1 cause Noonan syndrome. Nat Genet 2007;39:70-4.

[51] Swanson KD, Winter JM, Reis M, Bentires-Alj M, Greulich H, Grewal R, et al. SOS1 mutations are rare in human malignancies: implications for Noonan Syndrome patients. Genes Chromosomes Cancer 2008;47:253-9. 
[52] Tartaglia M, Pennacchio LA, Zhao C, Yadav KK, Fodale V, Sarkozy A, et al. Gain-of-function SOS1 mutations cause a distinctive form of Noonan syndrome. Nat Genet 2007;39:75-9.

[53] Narumi Y, Aoki Y, Niihori T, Sakurai M, Cave H, Verloes A, et al. Clinical manifestations in patients with SOS1 mutations range from Noonan syndrome to CFC syndrome. J Hum Genet 2008;53:834-41.

[54] Hart TC, Zhang Y, Gorry MC, Hart PS, Cooper M, Marazita ML, et al. A mutation in the SOS1 gene causes hereditary gingival fibromatosis type 1. Am J Hum Genet 2002;70:943-54.

[55] Jang SI, Lee EJ, Hart PS, Ramaswami M, Pallos D, Hart TC. Germ line gain of function with SOS1 mutation in hereditary gingival fibromatosis. J Biol Chem 2007;282:20245-55.

[56] Csiszar A, Wiebe C, Larjava H, Hakkinen L. Distinctive molecular composition of human gingival interdental papilla. J Periodontol 2007;78:304-14.

[57] Suy S, Anderson WB, Dent P, Chang E, Kasid U. Association of Grb2 with Sos and Ras with Raf-1 upon gamma irradiation of breast cancer cells. Oncogene 1997;15:53-61.

[58] Denayer E, Devriendt K, de Ravel T, Van Buggenhout G, Smeets E, Francois I, et al. Tumor spectrum in children with Noonan syndrome and SOS1 or RAF1 mutations. Genes Chromosomes Cancer 49:242-52.

[59] Watanabe T, Shinohara N, Moriya K, Sazawa A, Kobayashi Y, Ogiso Y, et al. Significance of the Grb2 and son of sevenless (Sos) proteins in human bladder cancer cell lines. IUBMB Life 2000;49:317-20.

[60] Timofeeva OA, Zhang X, Ressom HW, Varghese RS, Kallakury BV, Wang K, et al. Enhanced expression of SOS1 is detected in prostate cancer epithelial cells from African-American men. Int J Oncol 2009;35:751-60.

[61] Guerrero C, Rojas JM, Chedid M, Esteban LM, Zimonjic DB, Popescu NC, et al. Expression of alternative forms of Ras exchange factors GRF and SOS1 in different human tissues and cell lines. Oncogene 1996;12:1097-107.

[62] Sibilia M, Fleischmann A, Behrens A, Stingl L, Carroll J, Watt FM, et al. The EGF receptor provides an essential survival signal for SOS-dependent skin tumor development. Cell 2000;102:211-20. 
[63] Kardinal C, Konkol B, Lin H, Eulitz M, Schmidt EK, Estrov Z, et al. Chronic myelogenous leukemia blast cell proliferation is inhibited by peptides that disrupt Grb2-SoS complexes. Blood 2001;98:1773-81.

[64] Moeller SJ, Head ED, Sheaff RJ. p27Kip1 inhibition of GRB2-SOS formation can regulate Ras activation. Mol Cell Biol 2003;23:3735-52.

[65] Park R, Kim DH, Kim MS, So HS, Chung HT, Kwon KB, et al. Association of Shc, Cbl, Grb2, and Sos following treatment with 2,3,7,8-tetrachlorodibenzo-pdioxin in primary rat hepatocytes. Biochem Biophys Res Commun 1998;253:57781.

[66] Pierre S, Bats AS, Chevallier A, Bui LC, Ambolet-Camoit A, Garlatti M, et al. Induction of the Ras activator Son of Sevenless 1 by environmental pollutants mediates their effects on cellular proliferation. Biochem Pharmacol 2011;81:30413.

[67] Kratz CP, Niemeyer CM, Thomas C, Bauhuber S, Matejas V, Bergstrasser E, et al. Mutation analysis of Son of Sevenless in juvenile myelomonocytic leukemia. Leukemia 2007;21:1108-9.

[68] Tanizaki R, Katsumi A, Kiyoi H, Kunishima S, Iwasaki T, Ishikawa Y, et al. Mutational analysis of SOS1 gene in acute myeloid leukemia. Int J Hematol 2008;88:460-2.

[69] Abbott BD, Birnbaum LS. TCDD-induced altered expression of growth factors may have a role in producing cleft palate and enhancing the incidence of clefts after coadministration of retinoic acid and TCDD. Toxicol Appl Pharmacol 1990;106:418-32.

[70] Abbott BD, Birnbaum LS. Rat embryonic palatal shelves respond to TCDD in organ culture. Toxicol Appl Pharmacol 1990;103:441-51.

[71] Abbott BD, Birnbaum LS. Effects of TCDD on embryonic ureteric epithelial EGF receptor expression and cell proliferation. Teratology 1990;41:71-84. 


\section{${ }^{*}$ Graphical Abstraabsophila}



Eye development

$\downarrow$

Color vision

\section{Human}

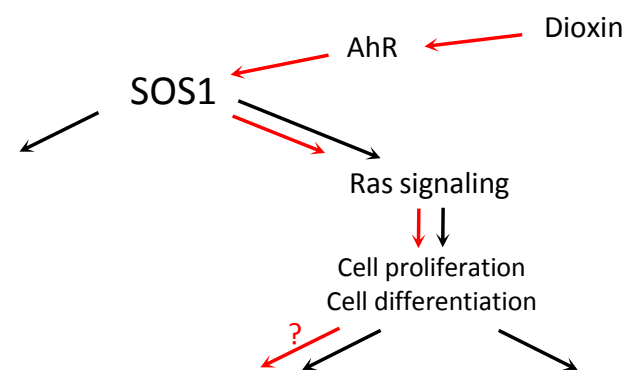

Cancer 
Figure $1 \mathrm{~A}$

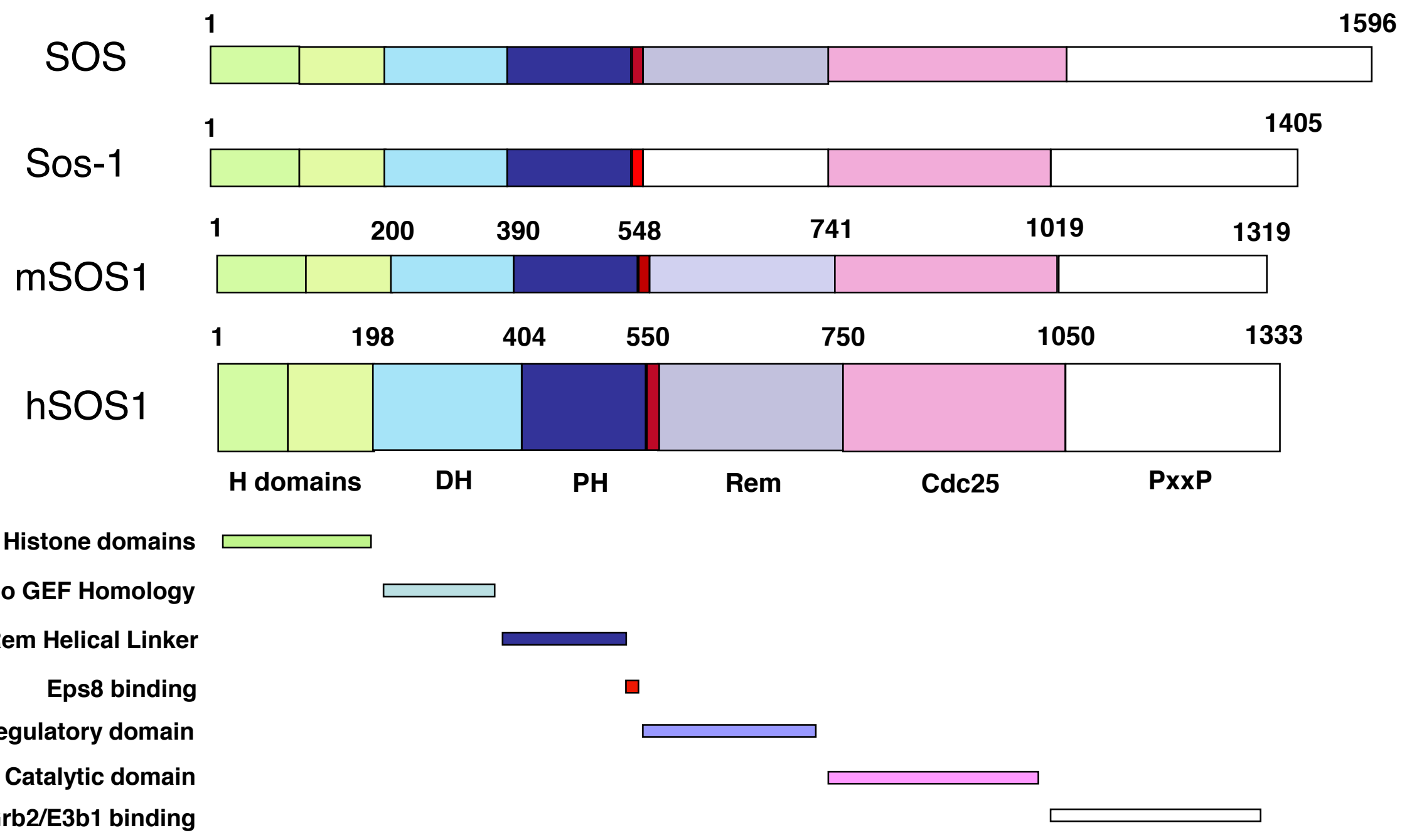


Figure 1B

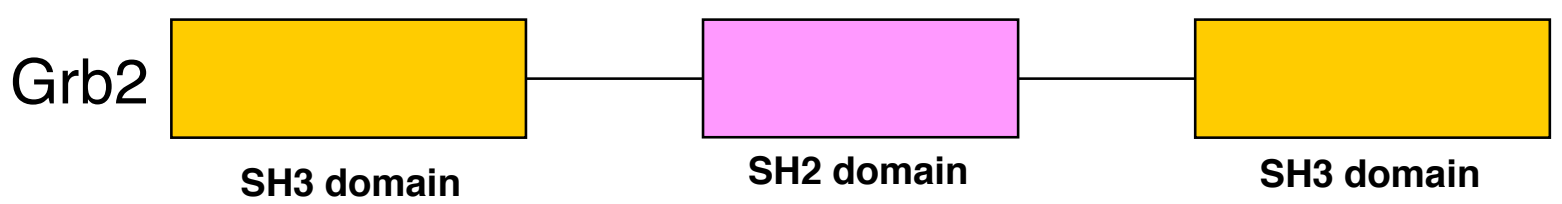

Figure 1C
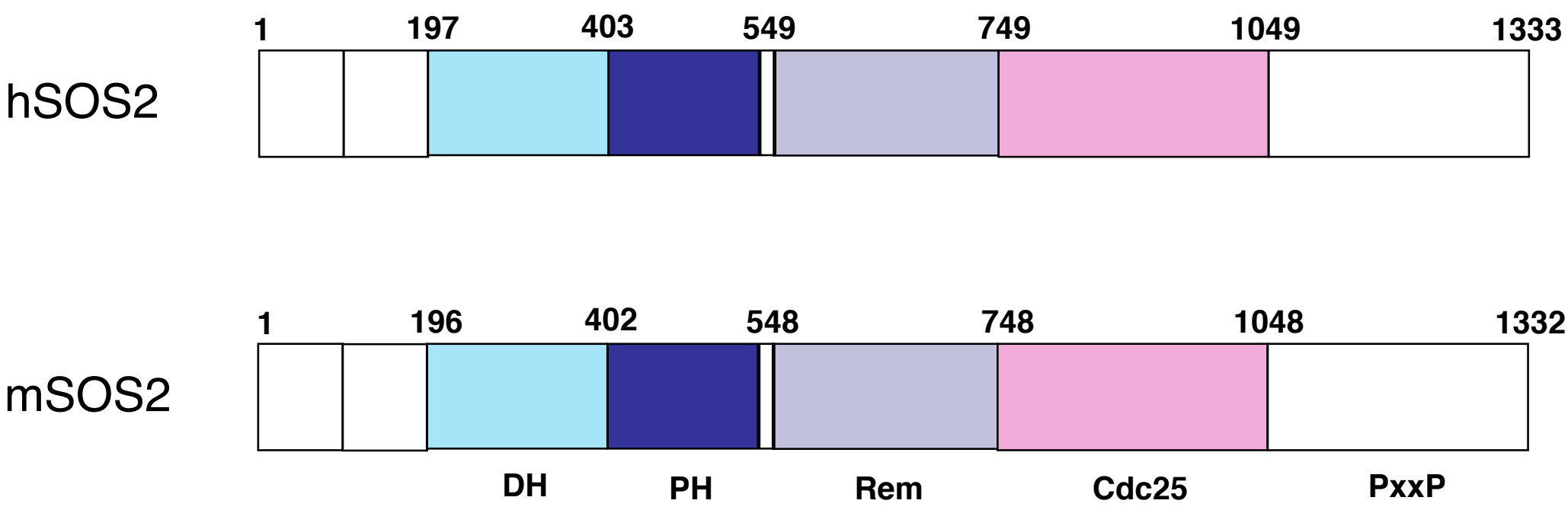
Tyrosine Kinase Receptor




Tyrosine Kinase Receptor


Actin remodeling JNK activation

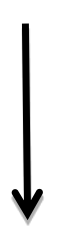

Cell migration

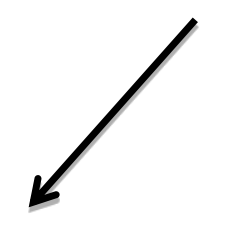

Differentiation 


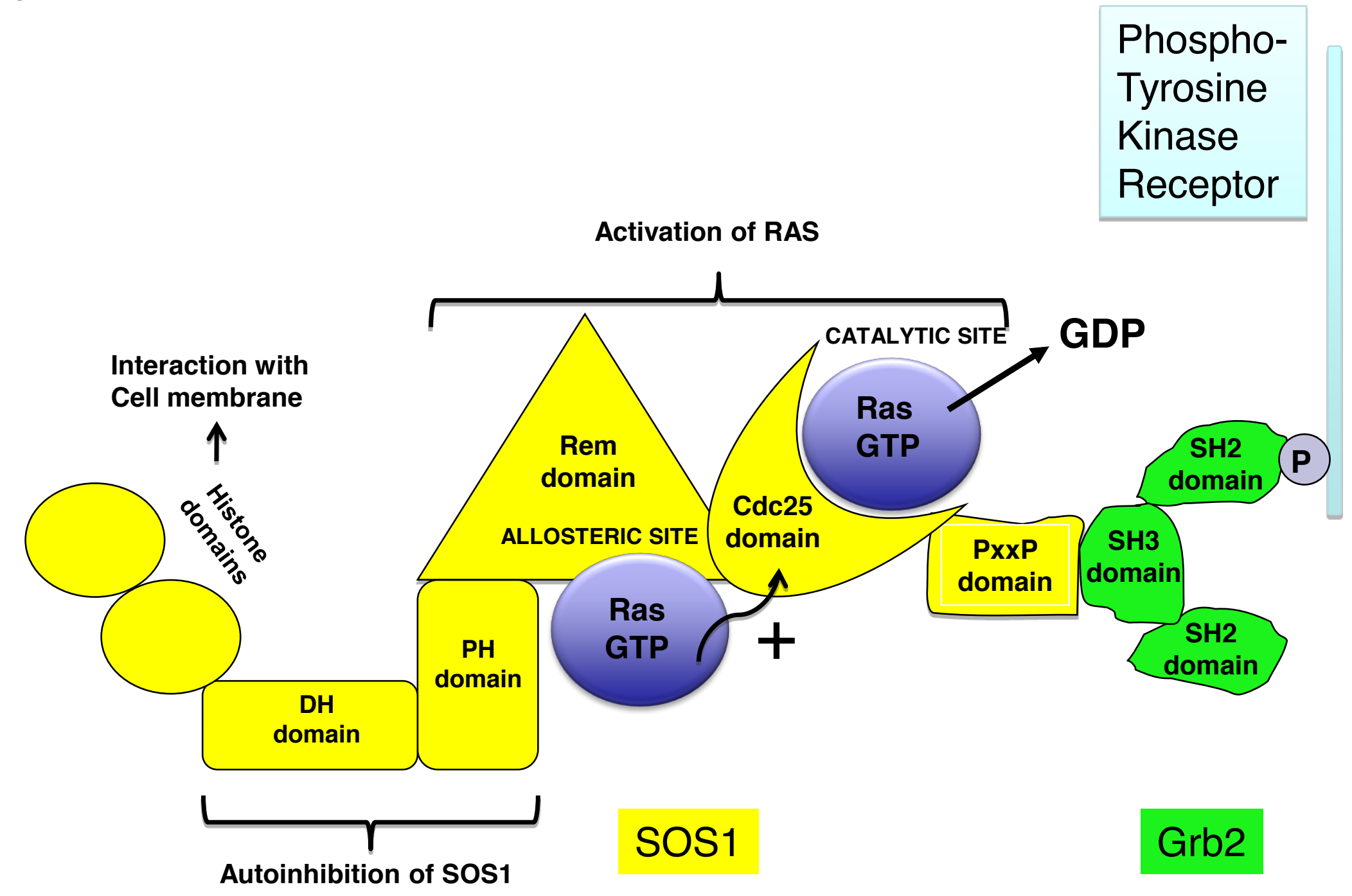




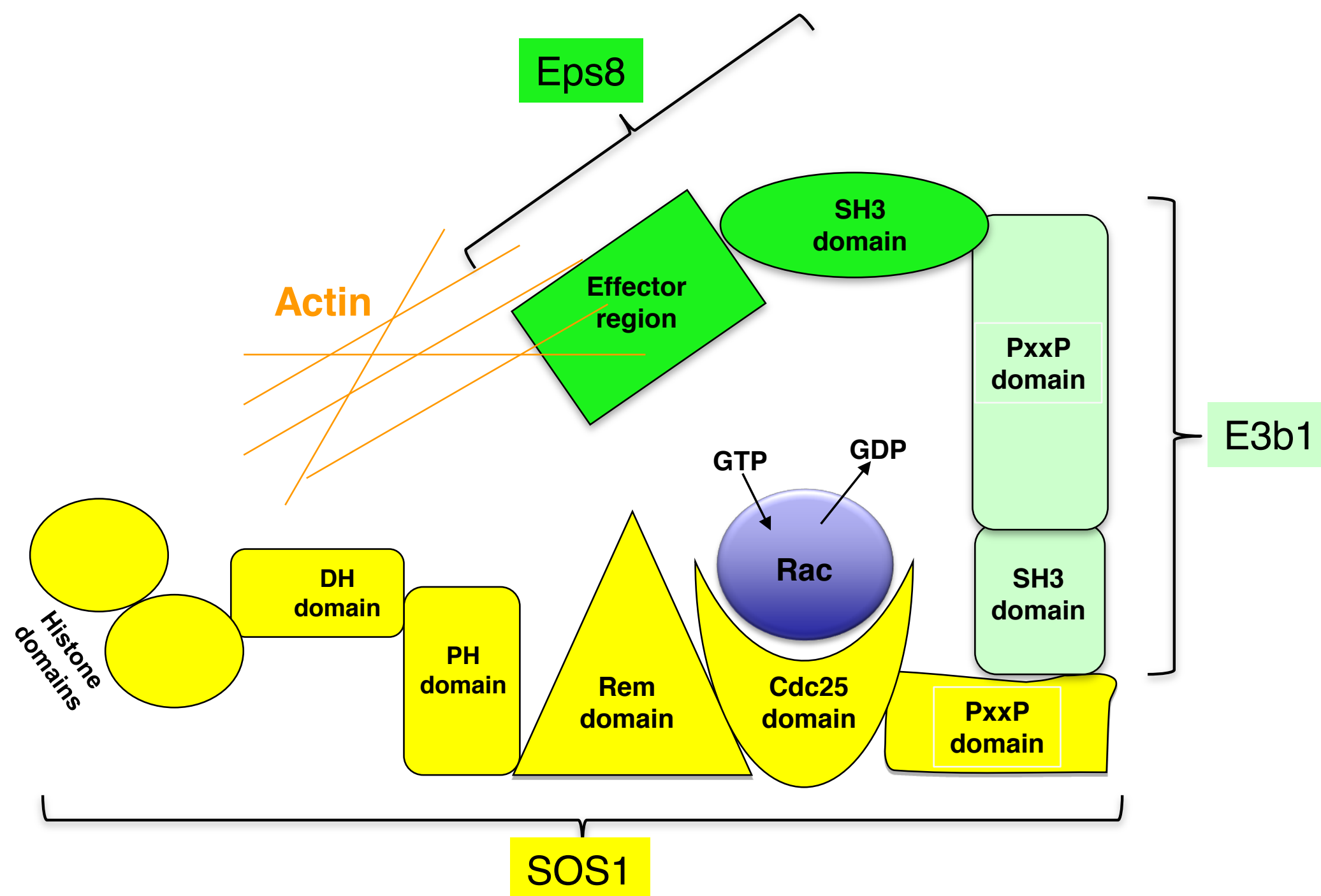


Figure 3

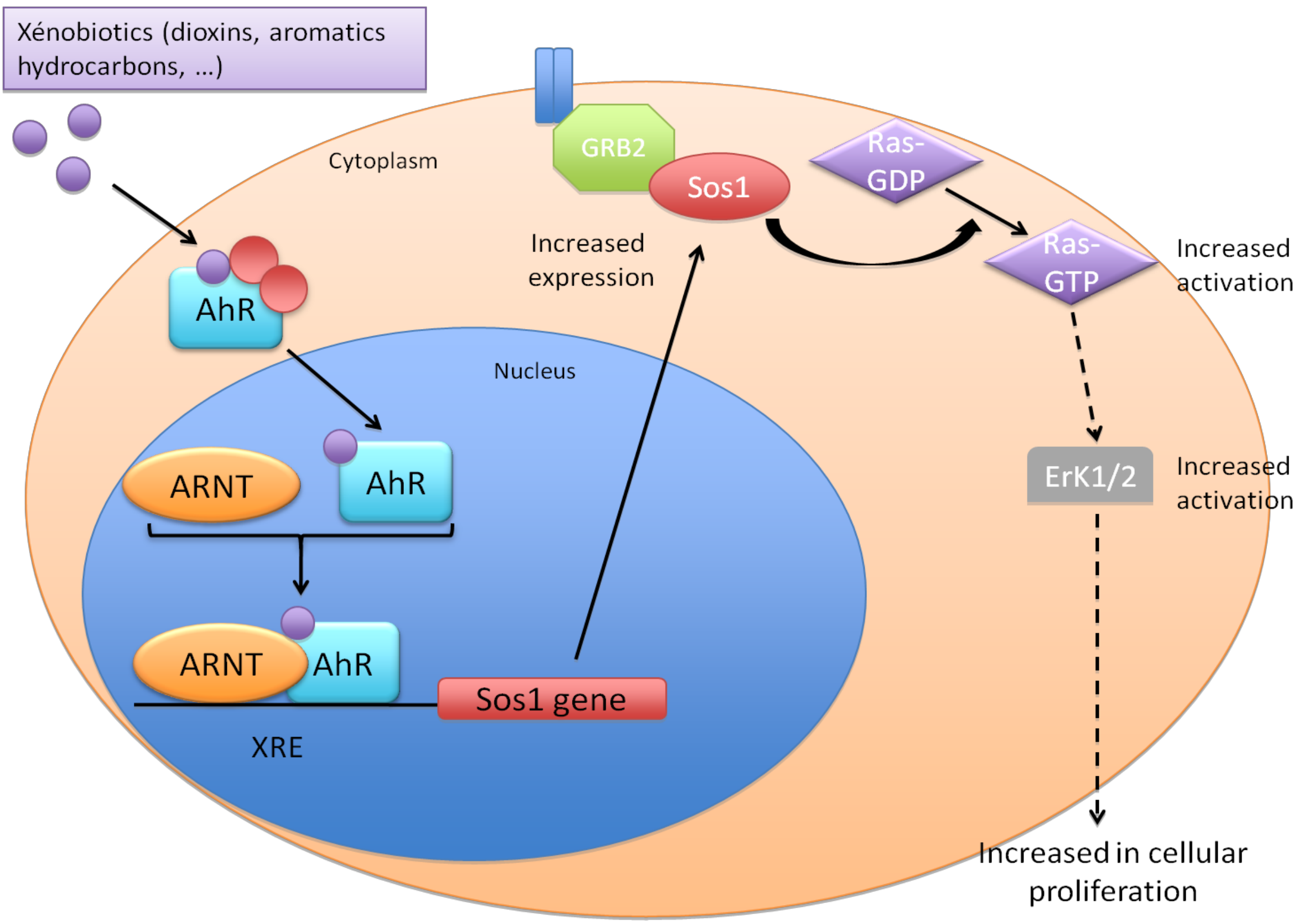

Xénobiotics (dioxins, aromatics

ydrocarbons, ....

\section{ARNT AhR}

XRE proliferation 
Figure $1 \mathrm{~A}$

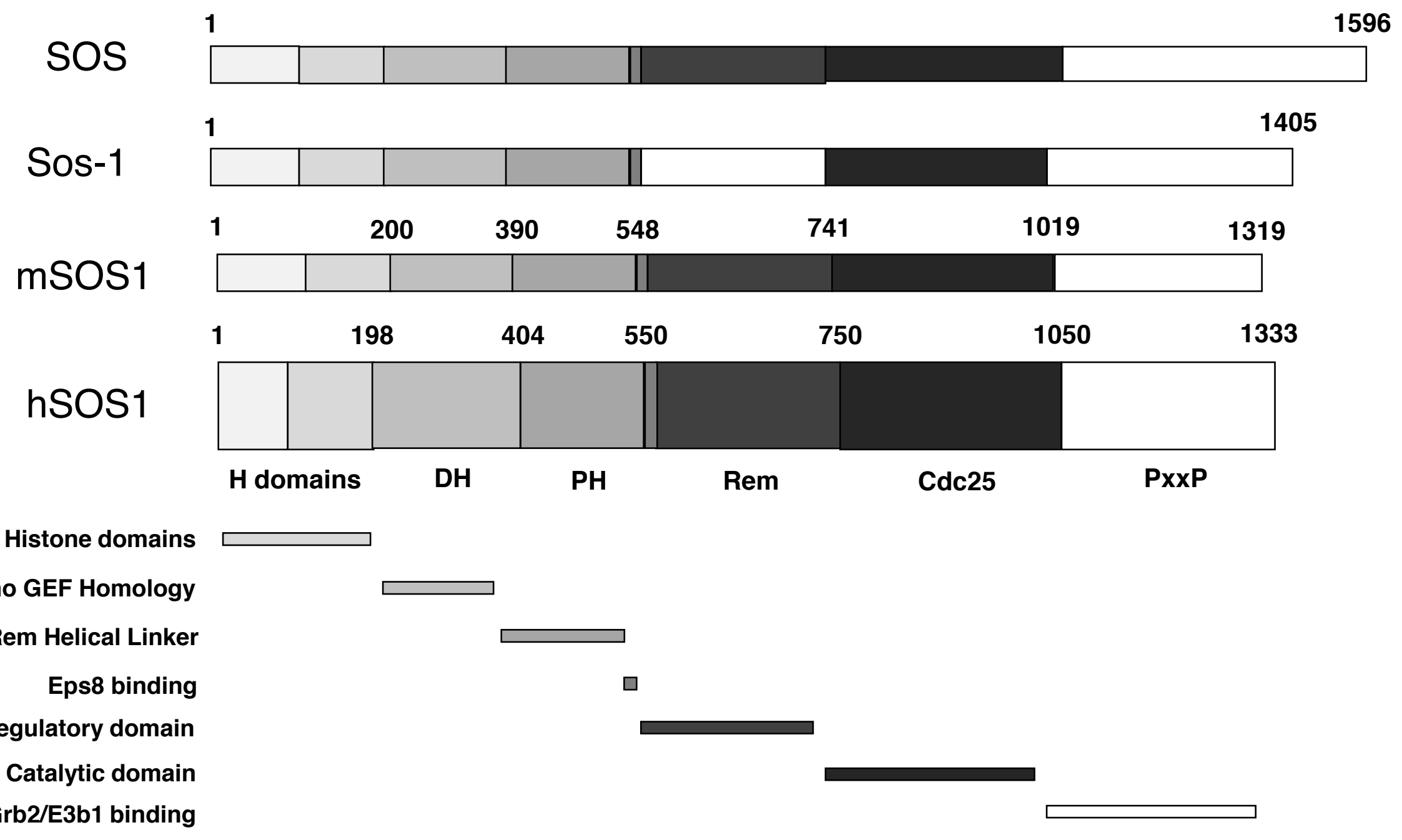


Figure 1B

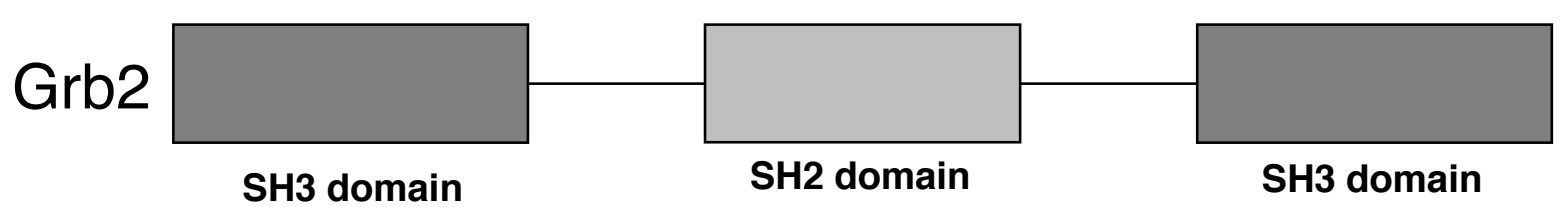

Figure 1C



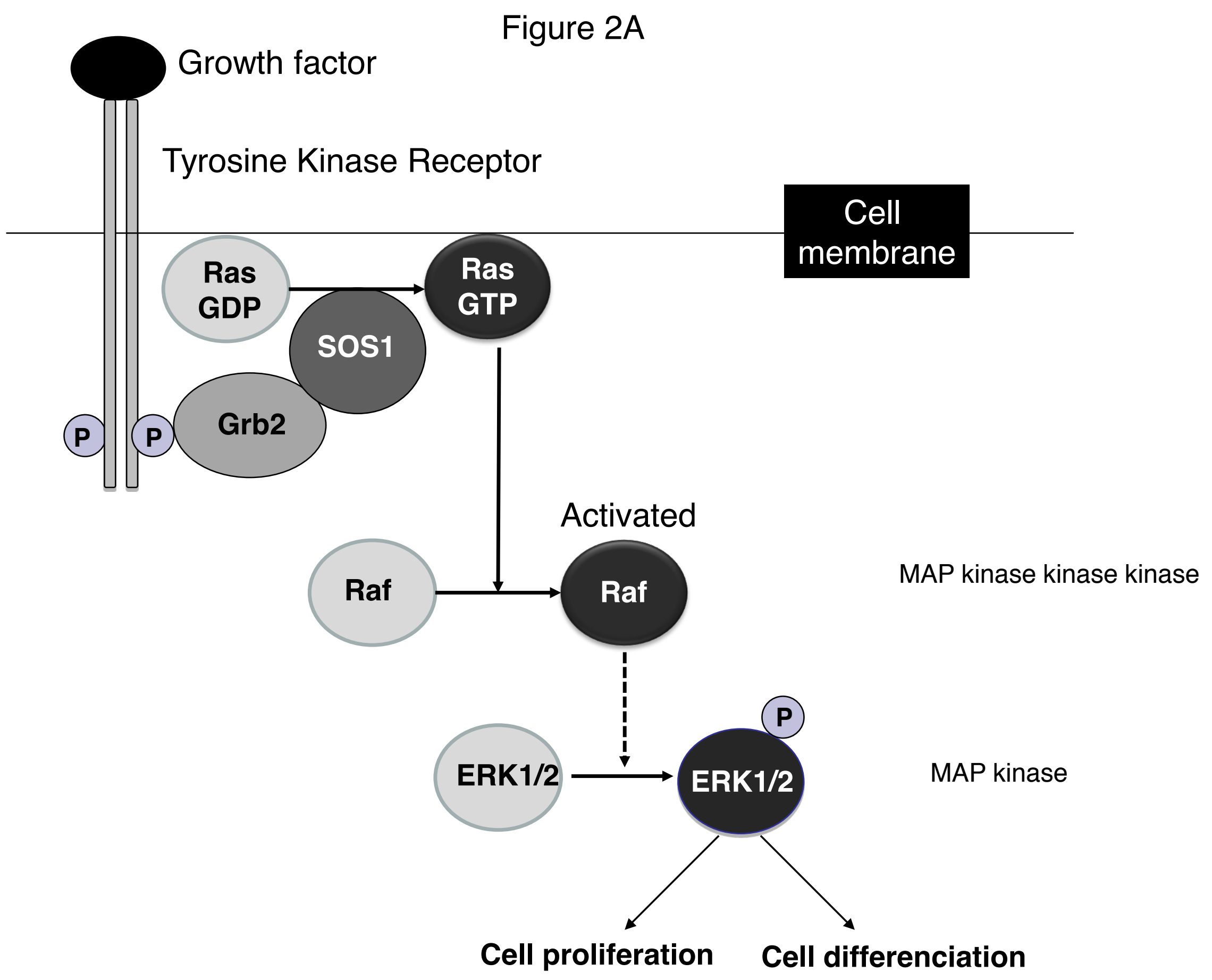



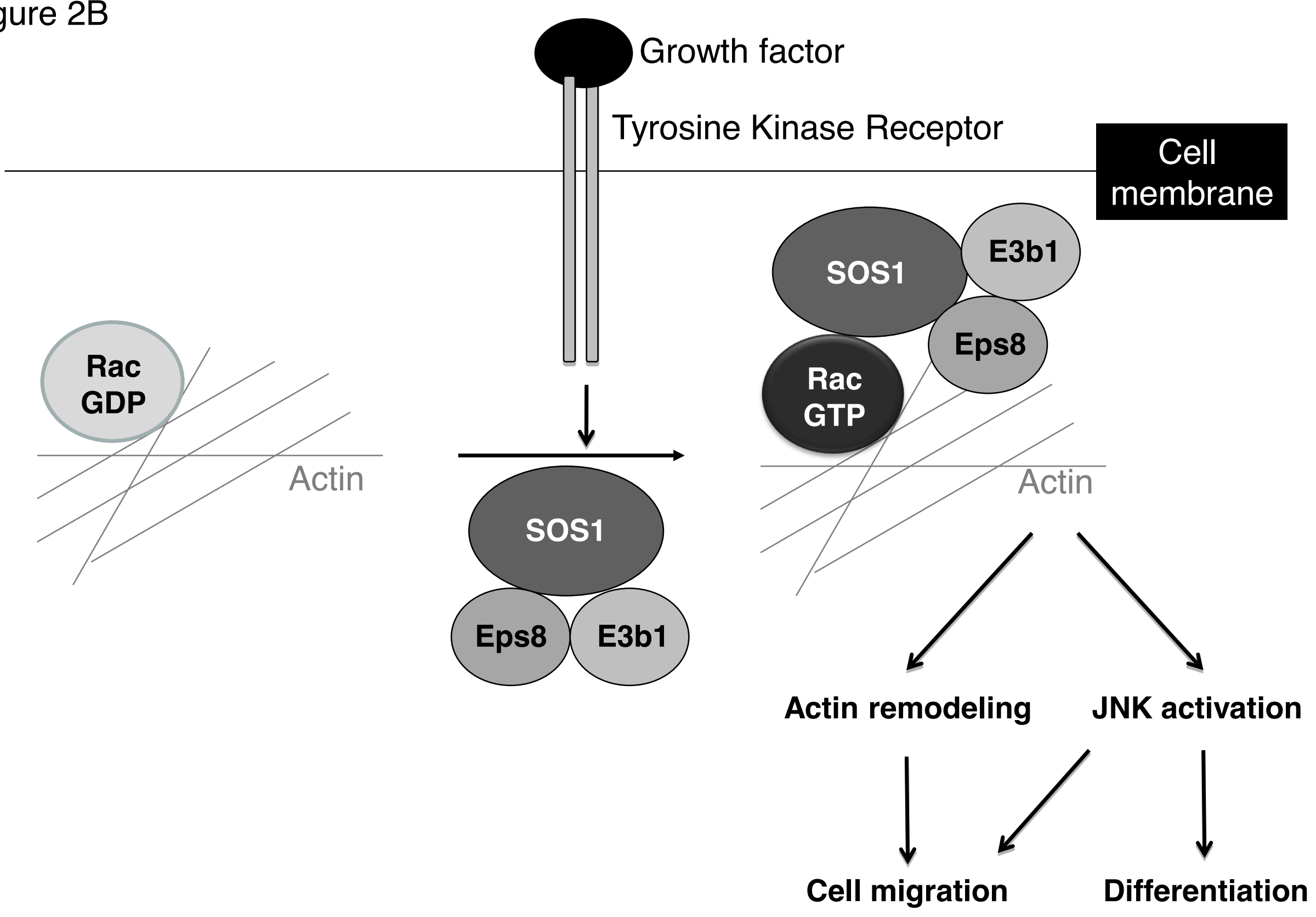


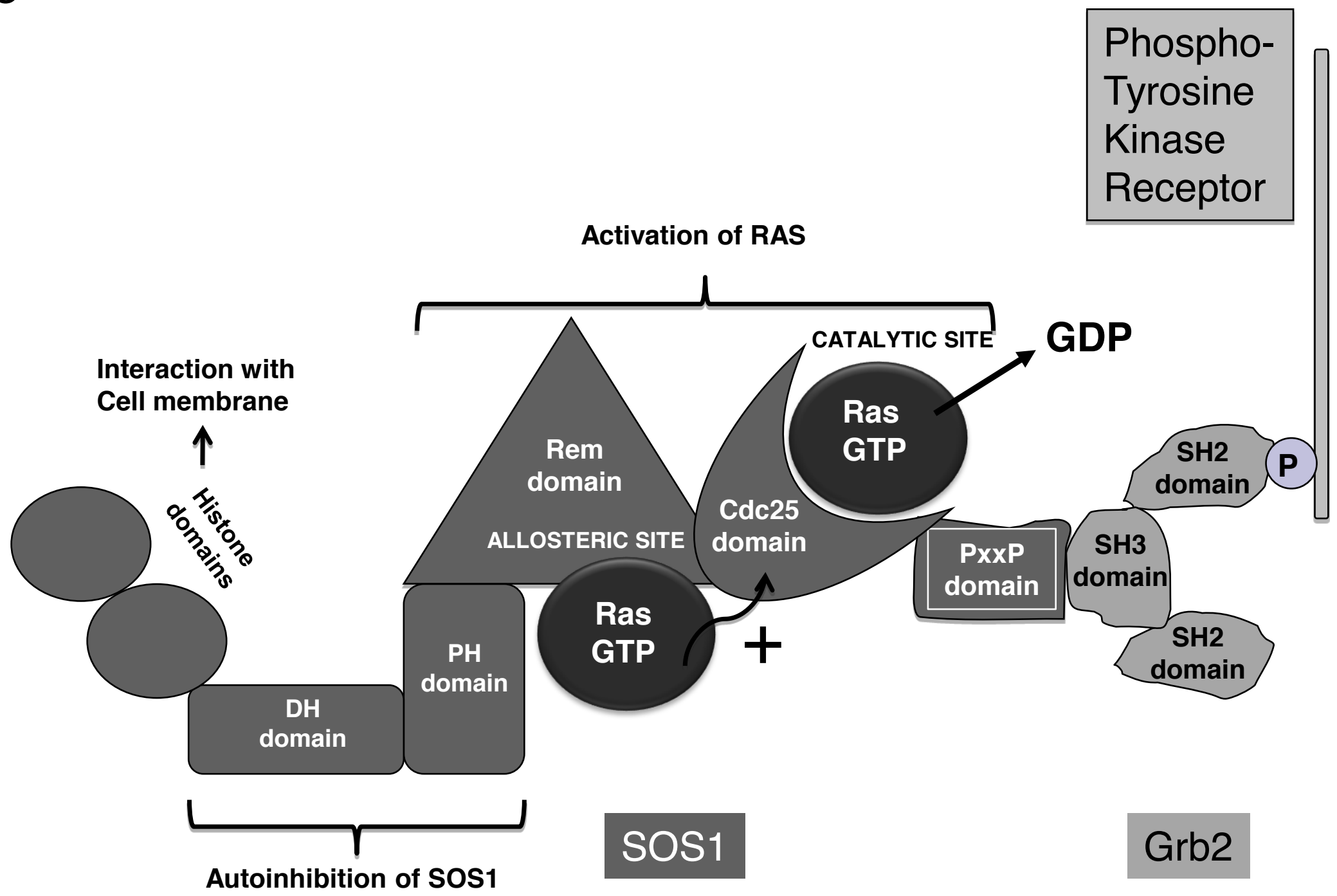




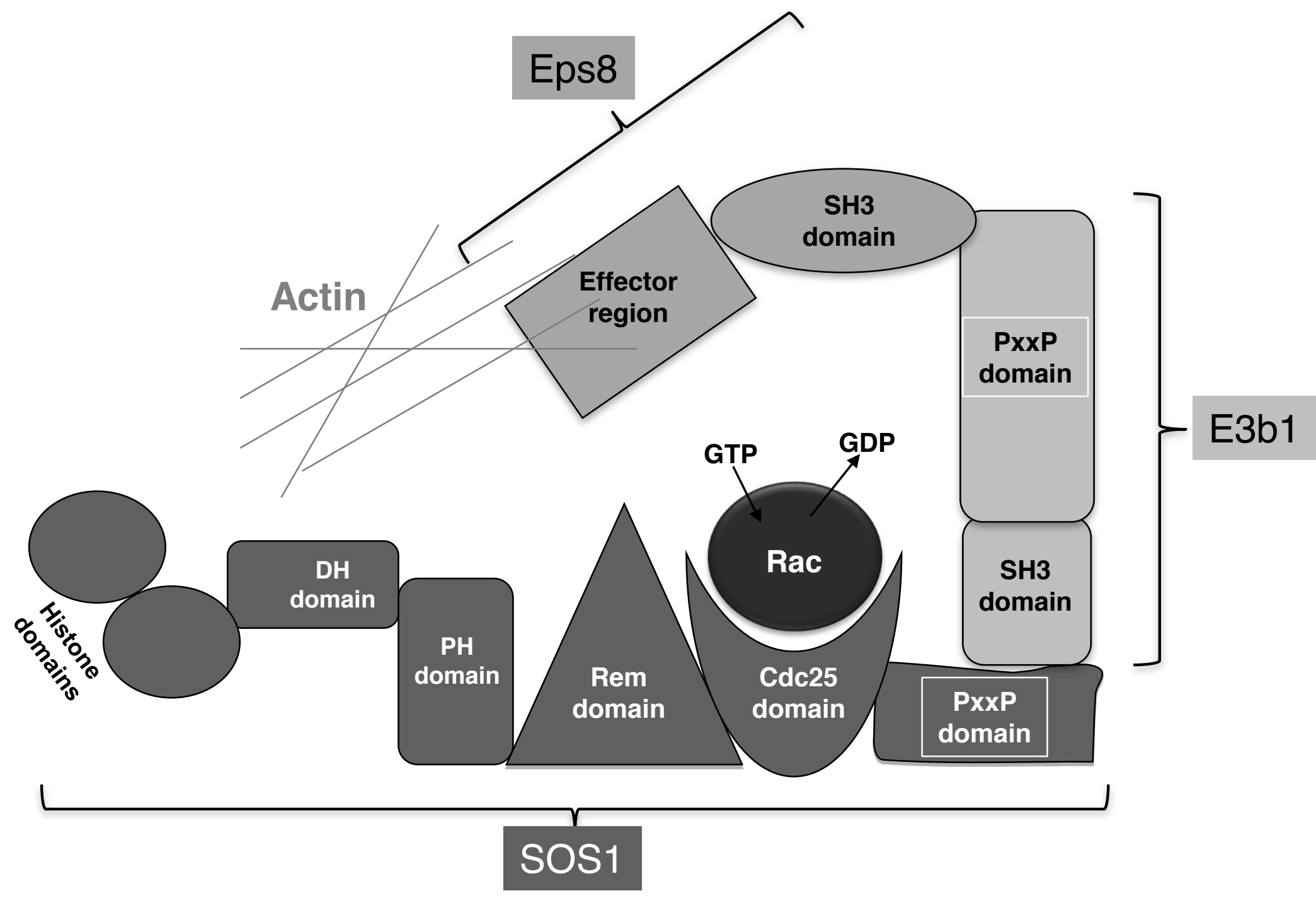


Figure 3



